\title{
Citywide preparedness for a pandemic: A cross- sectional survey of knowledge, attitudes, and practices about respiratory infection prevention in Bogotá, Colombia
}

\author{
Jorge Alberto Cortés ${ }^{1,2}$, Pilar Espitia ${ }^{3}$, Yuliet Liliana Rosero-Lasso ${ }^{1,2}$ \\ ${ }^{1}$ Departamento de Medicina Interna, Universidad Nacional de Colombia, Bogotá, D.C., Colombia \\ ${ }^{2}$ Hospital Universitario Nacional de Colombia, Universidad Nacional de Colombia, Bogotá, D.C., \\ Colombia \\ ${ }^{3}$ División de Salud Pública, Secretaría Distrital de Salud, Bogotá, D.C., Colombia
}

Introduction: Healthcare personnel plays an important role in the prevention of acute respiratory infections in hospital settings.

Objective: Our aim was to establish the level of knowledge about respiratory virus infections and the attitudes and practices among healthcare workers, leaders of infection control committees in hospitals of Bogotá, Colombia.

Materials and methods: We used a self-administered questionnaire of 28 items during the monthly meeting sponsored by the local health authority. "Yes or no" and "true or false" questions were applied to measure knowledge. Attitudes and practices were measured with a Likert-type scale according to the agreement degree.

Results: We surveyed 70 healthcare workers. Respondents demonstrated a good level of knowledge as $80 \%$ of them answered correctly more than five questions. A total of $54.4 \%$ showed a low degree of agreement when asked if their institutions have the policy to stay home when they are sick with respiratory symptoms and $67.1 \%$ never or rarely remain at home under such conditions.

Conclusion: Healthcare worker leaders of infection control committees in Bogotá's hospitals have adequate knowledge about the prevention of seasonal respiratory viruses. There is a need for implementing urgent sick leave policies as a measure to prevent the spread of potential coronavirus infections in hospitals.

Received: $29 / 04 / 2020$

Accepted: 08/06/2020

Published: 09/06/2020

Citation:

Cortés JA, Espitia P, Rosero-Lasso YL. Citywide preparedness for a pandemic: A cross-sectional survey of knowledge, attitudes, and practices about respiratory infection prevention in Bogota, Colombia. Biomédica. 2020;40(Supl.2):159-65.

https://doi.org/10.7705/biomedica.5526

Corresponding author:

Jorge Alberto Cortés. Departamento de Medicina Interna, Facultad de Medicina, Universidad Nacional de Colombia, Carrera 30 No 45-03, oficina 510, Bogotá, D.C., Colombia

Mobile: (57) (315) 3514013

jacortesl@unal.edu.co

\section{Author contributions:}

Jorge Alberto Cortés: design, data collection and analysis, initial and final version of the manuscript Pilar Espitia: data collection and analysis and final version of the manuscript

Yuliet Liliana Rosero-Lasso: data collection and analysis, initial and final version of the manuscript

Funding:

This work has no direct financial support.

Conflicts of interest:

Authors report no conflicts of interest relevant to this article.
Keywords: Coronavirus infections; health knowledge, attitudes, practice; Colombia; respiratory tract infections/prevention and control; infection control practitioners; health personnel.

Preparación de la ciudad para la pandemia: una encuesta de conocimientos, actitudes y prácticas sobre la prevención de infecciones respiratorias en Bogotá, Colombia

Introducción. El personal de salud juega un papel importante en la prevención de la diseminación de los virus respiratorios en los hospitales.

Objetivo. Establecer el nivel de conocimiento y determinar las actitudes y prácticas en relación con los virus respiratorios entre los encargados de los comités de infecciones de los hospitales de Bogotá.

Materiales y métodos. Los participantes respondieron una encuesta de 28 ítems durante una de las sesiones mensuales del comité de infecciones de la ciudad. Se midió el conocimiento y se formularon preguntas sobre las actitudes y las prácticas utilizando una escala de tipo Likert para evaluar la conformidad.

Resultados. Se encuestaron 70 trabajadores de salud. Los participantes tenían un buen nivel de conocimiento, ya que el $80 \%$ de los respondientes tuvieron cinco o más respuestas correctas. El 54,4 \% mostró un bajo nivel de conformidad en cuanto a si sus instituciones tenían una política de quedarse en casa en caso de síntomas respiratorios y $64,1 \%$ nunca o casi nunca se queda en casa cuando presenta dichos síntomas.

Conclusión. Los trabajadores de la salud que encabezan los comités de infecciones de los hospitales de Bogotá tienen un adecuado conocimiento de la prevención de los virus respiratorios. Deben implementarse políticas de quedarse en casa para el personal con síntomas gripales, con el fin de prevenir la potencial diseminación de virus en los hospitales.

Palabras clave: infecciones por coronavirus; conocimientos, actitudes y práctica en salud; infecciones del sistema respiratorio/prevención y control; profesionales para control de infecciones; personal de salud. 
Hospital-acquired respiratory viral infections can result in morbidity and mortality of hospitalized patients (1). In Colombia, viral circulation has the typical pattern of tropical countries as it occurs throughout the year but increases in the rainy seasons (April-June and September-December) demanding preparedness for a "viral season" at least twice a year. Influenza is the most commonly identified virus (2) but others also circulate regularly.

In December, 2019, an outbreak of severe acute respiratory syndrome coronavirus 2 (SARS-CoV-2) infection was reported in Wuhan, China, which rapidly spread across this and other countries (3-5) including American countries. SARS-CoV-2 can be transmitted effectively among humans and exhibits high potential for a pandemic (6). At the beginning of April, 2020, the World Health Organization (WHO) reported confirmed cases in the majority of American countries: the United States, Canada, Brazil, México, and Ecuador (7) suggesting ongoing circulation in the region. Colombia has been no exception and the pandemic peak will coincide with that of respiratory virus infections during the first rainy season of the year.

Bogotá, the largest city in the country, with over 7.4 million inhabitants, has the largest healthcare infrastructure. Healthcare personnel plays an important role in the prevention of acute respiratory infections in hospital settings (8), so it is essential that they have adequate knowledge about these infections and they should exert leadership in the strategies aimed at reducing the risk of hospitalized patients acquiring respiratory infections.

The present study aimed to determine the level of knowledge about respiratory virus infections and the attitudes and perceptions of healthcare worker leaders in infections control committees of hospitals in Bogotá and to establish a baseline to define educational priorities for the upcoming SARS-CoV-2 pandemic.

\section{Materials and methods}

\section{Population}

We conducted a cross-sectional study among leaders of infection control committees of hospitals in Bogotá, Colombia. Bogotá is the largest city in the country, with over 7.4 million inhabitants (without the surrounding small towns), and accounts for the largest number of healthcare institutions (69 second or third level hospitals).

We administered a questionnaire on February $14^{\text {th }}, 2020$, during the monthly meeting sponsored by the city's local health authority among those in charge of the infection control committees. No sample was taken from the assistants and the questionnaire was offered to all the participants. The respondents are responsible for guiding the decisions of the infection control committees in each second or third level hospital, establishing policies and practices related to infection control and aiding, together with public health authorities, in the implementation of surveillance, prevention, and control strategies of respiratory tract infections in the institutions during the "rainy season" in the city.

\section{Survey instrument}

A self-administered survey with 28 questions in Spanish was applied. The questionnaire comprised four main sections on: $(A)$ demographic characteristics, (B) knowledge, (C) attitudes, and (D) practices of healthcare worker leaders of infection control committees regarding prevention of respiratory virus infections. 
To measure knowledge, we asked "yes or no" and "true or false" questions. For questions on attitudes and practices, participants' agreement with a given statement was measured on a 5-point Likert scale ("strongly agree", "agree", "uncertain", "disagree", and "strongly disagree" or "never", "sometimes", "often", "most of the time", and "always").

The knowledge section included questions about viral transmission, prevention of viral infection through hand hygiene, gloves, patient identification, use of masks, and seasonal circulation of viruses in the country.

The attitudes section included the point of view of the respondent about sick leave policies, respiratory patient identification and education, and isolation practices.

The practices section included habits or uses of isolation and protection, hand hygiene, and patient education.

\section{Data analysis}

The data obtained were stored in a database using Microsoft Office Excel, version 2019, and analyzed with Stata ${ }^{\mathrm{TM}}$, version 16 . The results were reported in absolute values, proportions, and measures of central tendency (medians and interquartile ranges). Comparisons were done with the Wilcoxon test between continuous variables and with the chi-square test for proportions.

\section{Ethical aspects}

The questionnaire was designed to be individual and anonymous and participation was voluntary so informed consent was not specifically obtained. The data were kept confidential and the results did not individually identify the respondents.

\section{Results}

We surveyed 70 healthcare worker leaders from infection control committees in city hospitals. The majority $(84.3 \%)$ of the respondents were women. Occupations included nursing assistant, nurse, doctor, and others. A total of $81.4 \%$ of the respondents worked directly with the infection committee of their institution. Table 1 shows their demographic data.

\section{Knowledge}

Figure 1 shows the results obtained for the knowledge questions. Interestingly, we found that $58.0 \%(95 \% \mathrm{Cl}: 45.9-65.2)$ of the respondents considered that high-efficiency respirators and surgical masks are not equally effective for respiratory viral infection prevention.

Regarding the question about the season of respiratory virus circulation in Bogotá, most respondents $(64.1 \%, 95 \% \mathrm{Cl}: 51.4-71.0)$ knew that the circulation of these viruses occurs throughout the year; however, there is an important percentage that had incorrect knowledge about this issue.

Eighty percent of respondents answered more than five questions correctly. The median number of correct answers was 6 for nurses, 5.5 for physicians, and 4.5 for nurse assistants ( $p=0.016$ for the comparison between nurses and the assistants). Health care workers in III level hospitals had higher scores of correct answers ( 6 for the third level vs 5 for the second level hospitals, $p=0.036$ ). No effect on the scores was seen regarding the number of years of work. 
Table 1. Demographic characteristics of survey respondents $(\mathrm{N}=70)$

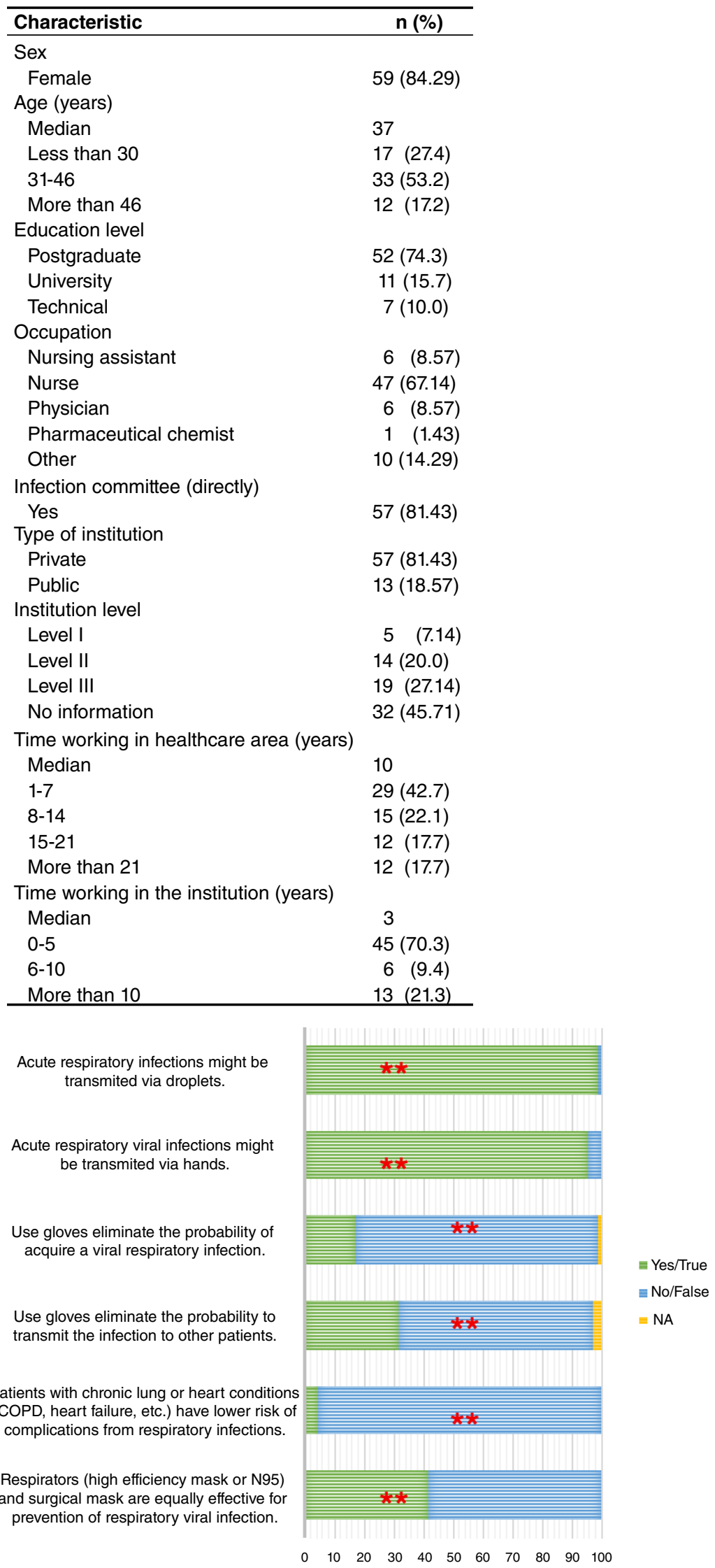


Figure 2. Attitudes regarding respiratory viral infections $(\mathrm{N}=70)$ NA: Question not answered

Figure 3. Practices regarding respiratory viral infections $(\mathrm{N}=70)$ NA: Question not answered

\section{Attitudes}

Figure 2 shows the results regarding the attitudes of the respondents. Most of the questions on attitudes were answered with a high degree of agreement. It is interesting to note that $57.5 \%$ of the respondents $(95 \% \mathrm{Cl}$ : $39.2-81.0$ ) had a low degree of agreement about the leave of absence policy in institutions when they have respiratory symptoms.

Most respondents reported that most of the time or always they perform hand hygiene before entering or exiting a patient's room with $86.4 \%(95 \% \mathrm{Cl}$ : 75.6-92.8) agreement in both cases. There were no differences in the degree of agreement between different occupations or complexity levels in the hospitals.

\section{Practices}

Figure 3 shows the results regarding the practices of the respondents. Most of them reported that they sometimes perform the practices shown in figure 3 . However, most respondents $(71.2 \%, 95 \% \mathrm{Cl}: 50.1-95.7)$ stated that they never or only sometimes remain at home when they have respiratory symptoms. There were no differences in the practices between occupations or levels of complexity.

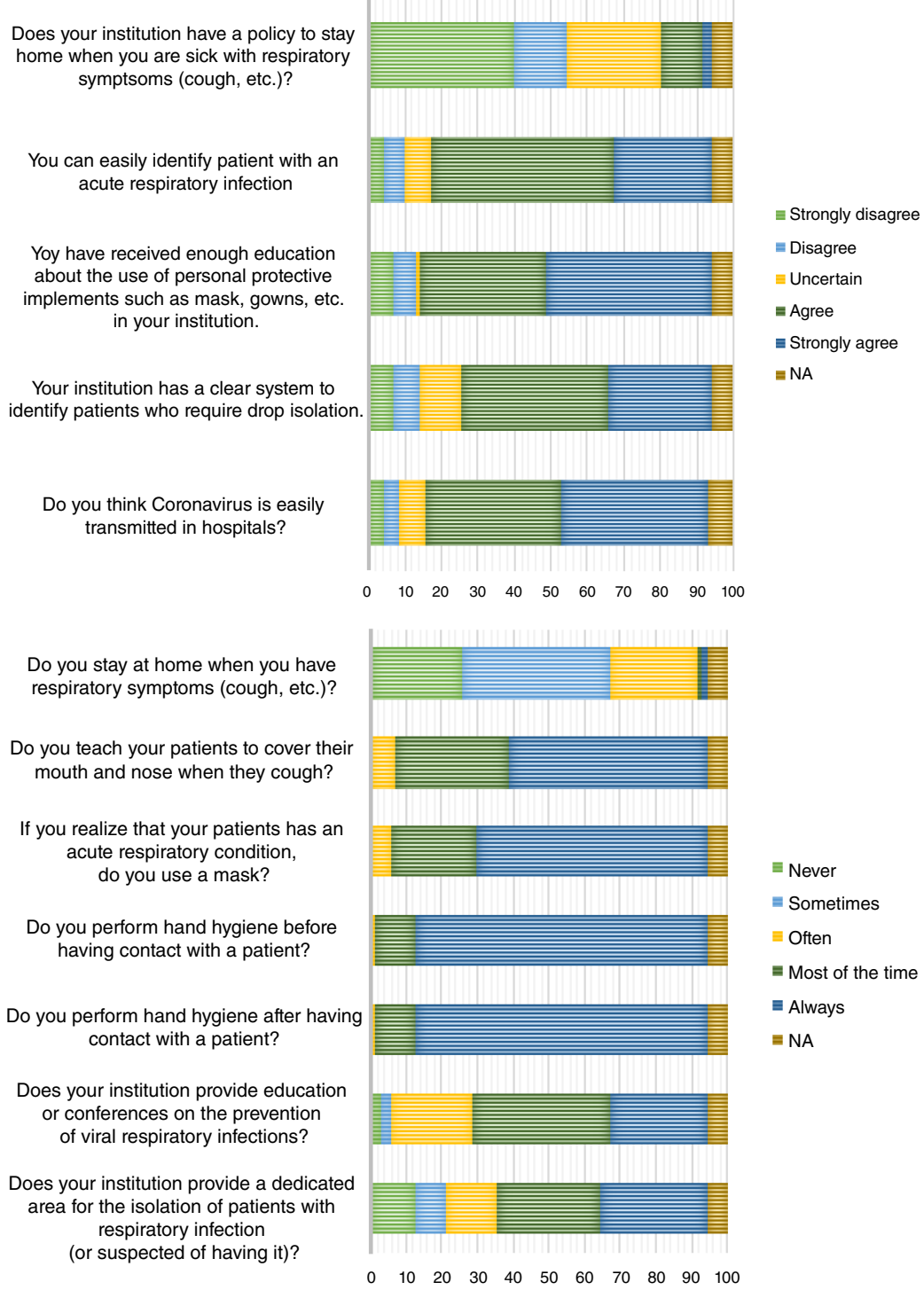




\section{Discussion}

Our results show that the leaders of infection control committees in Bogotá's hospitals have adequate knowledge about the prevention of seasonal respiratory viruses which evidences that they may be adequately prepared to face the dissemination of these viruses during the rainy season and that there is a baseline preparation for the SARS-COV2 pandemic. This fact is important since leaders are required to have an important level of knowledge and to be capable of systematically transmitting that knowledge to their coworkers and peers to ensure they have adequate knowledge and skills to prevent viral respiratory infection at hospitals (9).

Despite finding an adequate level of knowledge and skills, there are also some deficiencies in terms of basic prevention measures, such as hand hygiene, which is widely known as a very effective prevention measure for respiratory infections (10-12). It seems to be an important but endless task in infection control and prevention. Other misconceptions, such as the efficacy of respirators (N95) versus the traditional mask for respiratory infection prevention should be clarified among the personnel surveyed since it is known that there is no significant difference between the use of one or the other, even in the prevention of the influenza virus (13). Current CDC guidelines recommend the use of medical respirators only for healthcare personnel that needs protection from both airborne and fluid hazards (14). In a pandemic, the risk of a capacity crisis might put in danger health care workers due to a shortage of key personal protection elements, so the correct use of some of them is fundamental to prevent such shortage.

Responses about sick leave for healthcare workers show that there is a lack of regulation regarding policies to stay at home when they have respiratory symptoms. Although it has been shown that sick leave policies among healthcare workers are important in reducing the transmission of infections in the hospital, many hospitals in the United States do not have such policies to ensure restriction on direct patient care by sick hospital staff (15).

In the case of Colombia, the lack of these policies respond to several situations: no clear guidelines on the matter by the country's official entities, as well as economic reasons among the healthcare personnel since payment might be stopped or diminished because of local social security regulations (16). This sick leave policy and a clear understanding of the role of healthcare workers in virus transmission are important to limit the number of infections in the hospitals both in healthcare workers and in patients.

Our study has limitations. First, the survey was not validated before its application. Second, it was applied only to infection committee leaders as an indirect measure of the entire population of healthcare personnel in the hospitals of Bogotá to evaluate whether the city was prepared for an eventual SARS CoV-2 pandemic.

Despite these limitations, we consider that our findings can stimulate the design of interventions to strengthen knowledge, modify attitudes, and optimize practices regarding the prevention of acute respiratory infections and to promote the implementation of policies such as sick leave as a potential intervention to prevent the spread of acute respiratory infections in hospitals.

\section{Acknowledgments}

To all the members of the Infection Control Committee of the hospitals in Bogotá, Colombia. 


\section{References}

1. Chow EJ, Mermel LA. Hospital-acquired respiratory viral infections: Incidence, morbidity, and mortality in pediatric and adult patients. Open Forum Infect Dis. 2017;4:ofx006.

https://doi.org/10.1093/ofid/ofx006

2. Remolina YA, Ulloa MM, Vargas H, Díaz L, Gómez SL, Saavedra A, et al. Viral infection in adults with severe acute respiratory infection in Colombia. Plos One. 2015;10:e0143152. https://doi.org/10.1371/journal.pone.0143152

3. Guan WJ, Ni ZY, Hu Y, Liang WH, Ou CQ, He JX, et al. Clinical characteristics of coronavirus disease 2019 in China. N Eng J Med. 2020;382:1708-20. https://doi.org/10.1056/NEJMoa2002032

4. Munster VJ, Koopmans M, van Doremalen N, van Riel D, de Wit E. A novel coronavirus emerging in China - Key questions for impact assessment. New Eng J Med. 2020;382:6924. https://doi.org/10.1056/NEJMp2000929

5. Zu ZY, Jiang MD, Xu PP, Chen W, Ni QQ, Lu GM, et al. Coronavirus disease 2019 (COVID-19): A perspective from China. Radiology. 2020:200490. https://doi.org/10.1148/radiol.2020200490

6. Lai CC, Shih TP, Ko WC, Tang HJ, Hsueh PR. Severe acute respiratory syndrome coronavirus 2 (SARS-CoV-2) and coronavirus disease-2019 (COVID-19): The epidemic and the challenges. Int J Antimicrob Agents 2020;55:105924. https://doi.org/10.1016/j.ijantimicag.2020.105924

7. World Health Organization. Coronavirus disease 2019 (COVID-19). Geneva: World Health Organization; 2020.

8. Sydnor ER, Perl TM. Hospital epidemiology and infection control in acute-care settings. Clin Microbiol Rev. 2011;24:141-73. https://doi.org/10.1128/CMR.00027-10

9. Aldohyan M, Al-Rawashdeh N, Sakr FM, Rahman S, Alfarhan Al, Salam M. The perceived effectiveness of MERS-CoV educational programs and knowledge transfer among primary healthcare workers: A cross-sectional survey. BMC Infect Dis. 2019;19:273. https://doi.org/10.1186/s12879-019-3898-2

10. Finco G, Musu M, Landoni G, Campagna M, Lai A, Cabrini L, et al. Healthcare-associated respiratory infections in intensive care unit can be reduced by a hand hygiene program: $\mathrm{A}$ multicenter study. Austral Crit Care. 2018;31:340-6. https://doi.org/10.1016/j.aucc.2017.10.004

11. Fulchini R, Kohler P, Kahlert CR, Albrich WC, Kuhn R, Hoffmann M, et al. Hand hygiene adherence in relation to influenza season during 6 consecutive years. Am J Infect Control. 2018;46:1311-4. https://doi.org/10.1016/j.ajic.2018.04.203

12. Lee YF, McLaws M-L, Ong LM, Amir Husin S, Chua HH, Wong SY, et al. Hand hygiene promotion delivered by change agents - Two attitudes, similar outcome. Infect Control Hosp Epidemiol. 2020;41:273-9. https://doi.org/10.1017/ice.2019.339

13. Radonovich LJ, Jr, Simberkoff MS, Bessesen MT, Brown AC, Cummings DAT, Gaydos CA, et al. N95 Respirators vs. medical masks for preventing influenza among health care personnel: A randomized clinical trial. JAMA. 2019;322:824-33. https://doi.org/10.1001/jama.2019.11645

14. Centers for Disease Control and Prevention. Frequently asked questions about personal protective equipment. 2020. Accessed: March 8, 2020. Available at: https://www.cdc. gov/coronavirus/2019-ncov/hcp/respirator-use-faq.html?fbclid=IwAROyMI2clenEL T1YUkpJp38t4458ahoq2rkMA1xH8vimt-NL8fP5uAj4SU

15. Chow EJ, Smit MA, Mermel LA. Visitor screening and staff sick leave policies in US hospitals. Infect Control Hosp Epidemiol. 2018;39:1006-8. https://doi.org/10.1017/ice.2018.131

16. Saiman L, Wilmont S, Hill-Ricciuti A, Jain M, Collins E, Ton A, et al. Knowledge, attitudes, and practices of pediatric long-term care facility staff regarding infection control for acute respiratory infections and influenza vaccination. J Ped Infect Dis. 2019. https://doi.org/10.1093/ipids/piz090 